\title{
Tolerar la costumbre: Ferias y romerías en el siglo XVIII*
}

\section{Manuel Peña Díaz}

Universidad de Córdoba

RESUMEN: Desde mediados del siglo XVIII, los gobiernos borbónicos se obsesionaron con la vigilancia del orden público, tras el motín de Esquilache pesó mucho el miedo a la multitud. Mientras, las autoridades episcopales, cercanas al jansenismo y con una aversión instintiva hacia lo popular, intentaron desterrar las supersticiones y la inmoralidad de los actos religiosos populares que el disciplinamiento tridentino no había conseguido erradicar. Pero tampoco las reformas y las represiones aplicadas durante el siglo XVIII tuvieron el alcance deseado. La actitud de la Iglesia fue prudente, limitándose a reafirmar la imagen de su autoridad y a erradicar lo que consideraba que profanaba notoriamente y en exceso. Esta actitud fue similar a la del Gobierno, si la represión podía provocar tensiones y sonoras protestas era mejor seguir tolerando la costumbre. A partir de numerosos indicios documentales sobre ferias y romerías, en este estudio de historia socio-cultural de la vida cotidiana se analizan las transgresiones, resistencias y negociaciones que se establecieron cuando las autoridades intentaron rematar el inacabado proyecto de disciplinamiento tridentino.

\section{PAlabRas ClaVE: Tolerancia; vida cotidiana; fiestas, siglo XVIII; historia cultural.}

\section{Tolerate the Custom: Fairs and Romerias in the Eighteenth Century}

ABSTRACT: Since the middle of the 18th Century, the Bourbon governments became obsessed with the public order vigilance, because of Esquilache's riot caused fear of the crowd. In the meantime the episcopal authorities close to Jansenism, and adversaries of the popular base, attempted to banish

* Archivo Histórico Nacional (AHN), Archivo Municipal de Córdoba (AMCO), Archivo Histórico Diocesano de Jaén (AHDJ) 
the superstitious, and inmoral popular religious acts that Tridentine discipline had not got to eradicate. Even though the changes and the repressions applied during the 18th Centurie had the hoped outcomes. The Church attitude was cautious and limited to reassert the image of its power, and to eradicate what were considered that the governmental reforms desecrated a lot. This attitude was similar to the civil Government. If the activated repression caused tensions and complaints, it would have be better to go on tolerating the Custom. From the large documentary signs about fairs, and local religious festivities, this paper examine a socio-cultural daily life related to transgressions, resistances, and established negotiations when the rulers tried to accomplish the discipline Tridentine Project.

KEY WORDS: Tolerance; everyday life; feasts; 18th century; cultural history.

\section{TOLERANCIAS COTIDIANAS ${ }^{1}$}

Desde la década de los noventa del siglo XX los historiadores no solo han ido matizando la noción seductora de convivencia, también la de disciplina, la de intolerancia, incluso la de coexistencia ${ }^{2}$. Sin embargo, se continúa asociando de manera exclusiva las prácticas (in)tolerantes al ámbito de las formas complejas de la vida religiosa. Incluso hasta la propuesta más cercana a la historia de la vida cotidiana se ha centrado en la tolerancia y las actitudes y creencias de la gente común ${ }^{3}$. Joseph Perez ha recordado que el significado de tolerar en los siglos XVI, XVII y XVIII no se relacionaba con el aspecto religioso, sino con en el acto diario de soportar algo, y no castigarlo aunque lo mereciese según la ley o la costumbre ${ }^{4}$. En el Diccionario de Autoridades (1737), donde no se recoge intolerancia, tanto tolerable, tolerar como tolerancia tiene un significado negativo:

Tolerable: Sufrible, llevadero y que se puede aguantar.

Tolerancia: Sufrimiento, paciencia, aguante. Es voz puramente latina. Vale también permisión, y disimulo de lo que no se debiera sufrir sin castigo del que lo ejecuta. Lat. Indulgentia.

1 Proyecto de Investigación «Inquisición, Cultura y Vida Cotidiana en el Mundo Hispánico (XVI-XVIII)» (HAR2011-27021).

2 DODDS Y GLICK, 1992; OLIVARI, 2005; MORENO, 2010.

3 SCHWARTZ, 2010.

4 PEREZ, 2011. 
Tolerar: Sufrir, llevar con paciencia. Vale también disimular, o permitir algunas cosas, que no son lícitas, sin castigo del delincuente, pero sin dispensarlas expresamente ${ }^{5}$.

Como ejemplo se incluyó el uso del verbo tolerar en la Empresa 21 de Saavedra Fajardo. Publicada en 1640, aunque posiblemente ya redactada hacia 1612, esta empresa trata sobre como la ley debe regir y corregir, y advierte del daño que produce la multiplicidad de leyes si éstas no se cumplen: «Si queda sin castigo la transgresión de las pragmáticas, se pierde el temor y la vergüenza». Para Saavedra el principal conflicto en la inobservancia de las leyes era la preeminencia que se otorgaba a las costumbres, en tanto que resistencia popular:

Las costumbres son leyes, no escritas en el papel, sino en el ánimo y memoria de todos, y tanto más amadas, cuanto no son mandato, sino arbitrio, y una cierta especie de libertad, y así, el mismo consentimiento común que las introdujo y prescribió las retiene con tenacidad, sin dejarse convencer el pueblo, cuando son malas, que conviene mudadlas.

Pero si en la imposición de una ley sobre una costumbre surgían tensiones, del signo que fuesen, Saavedra recurría a la tolerancia: «Por lo cual es también más sano consejo tolerarlas que quitarlas. El príncipe prudente gobierna sus Estados sin innovar las costumbres; pero, si fueren contra la virtud o la religión corríjalas con gran tiento, haciendo capaz de la razón al pueblo» ${ }^{6}$. Sin dejar de lado el debate de la época sobre la prudencia del príncipe y los límites del poder, y sobre el antimaquiavelismo y el tacitismo de los pensadores españoles, nos interesan aquí las reflexiones de Saavedra en torno al incumplimiento de leyes por la relación que establecía por su impacto en la vida cotidiana: «No es menos dañosa la multiplicidad de las pragmáticas para corregir el gobierno, los abusos de los trajes y gastos superfluos, porque con desprecio se oyen y con mala satisfacción se observan. Una pluma las escribe y esa misma las borra (...) La reputación del príncipe padece cuando los remedios que señala, o no obran o no se aplican» (Empresa 21). Ciertamente, no era ninguna novedad esta advertencia sobre los inobservancia de las leyes. El mismo Cervantes puso en boca de don Quijote una semejante recomendación a Sancho antes de que ejerciese como gobernador de Barataria:

No hagas muchas pragmáticas, y si las hicieres, procura que sean buenas, y sobre todo que se guarden y cumplan, que las pragmáticas que no se guardan lo mismo es que si no lo fuesen, antes dan a entender que el príncipe que tuvo discreción

5 Diccionario de la lengua española, Madrid, Imprenta de la Real Academia, 1737, V: 290.

6 SAAVEDRA FAJARDO, 1988. 
y autoridad para hacerlas no tuvo valor para hacer que se guardasen; y las leyes que atemorizan y no se ejecutan, vienen a ser como la viga, rey de las ranas, que al principio las espantó, y con el tiempo la menospreciaron y se subieron sobre ella ${ }^{7}$.

Los moralistas casuistas consideraban la costumbre una de las excepciones que podían librar a un cristiano de un pecado. Por ejemplo, para el padre Echarri no era aceptable trabajar en los días festivos, si son obras «serviles o corporales»; sin embargo, entre las excepciones, contemplaba que los mercaderes no pudiesen negociar por la puerta de la calle, pero sí lo hicieran «por la parte de adentro»: «en esto se podrá estar a la costumbre, cuando interviniere justa causa». Del mismo modo, para trabajar en tiempo festivo se podía pedir la dispensa al Obispo, al Vicario o al párroco porque «es lícito por la costumbre tolerada y permitida $»^{8}$.

A pesar de las numerosas prohibiciones referidas a indumentaria, teatro $\mathrm{u}$ otras celebraciones, con los Austrias y con los Borbones, la tolerancia de la costumbre formó parte de las estrategias de todos los gobiernos, civiles y eclesiásticos. Así las transgresiones reiteradas de esas normas pueden entenderse como consecuencia de una permanente negociación cotidiana entre la defensa de la costumbre y la imposición de leyes. Un siglo más tarde, y en plena ofensiva del reformismo borbónico, Campomanes admitía en su Discurso sobre la educación de la educación popular (1775) que las costumbres tenían tanto poder como las leyes en todos los pueblos. Su propuesta educadora se centraba en el modo de que las gentes fuesen honradas, para ello había que «infundirles costumbres virtuosas y persuadirles de la ventaja que les producirá». Si se trabajaba en ese sentido se superaba la debilidad derivada del incumplimiento de las leyes, ya que para aplicarlas «prohibiendo y castigando; requieren prueba de los delitos o faltas; y son necesarias varias formalidades para imponer conforme a derecho los escarmientos. La compasión suele debilitar el rigor de la ley, y el que peca sin testigos que le delaten, se cree libre» ${ }^{9}$. A fines del siglo XVIII, Jovellanos reconocía una tensión similar a la formulada por Saavedra o por Campomanes. En su Memoria sobre los espectáculos y diversiones públicas, y al tratar sobre la prohibición que Carlos III había hecho de numerosas fiestas, comentó:

Tal vez de aquí se podría pasar sin inconveniente al restablecimiento de las máscaras, que así como fueron recibidas con gusto general, tampoco fueron abolidas sin general sentimiento. Aún parece que la opinión pública lucha por restaurarlas, pues que se repiten y toleran en algunas partes, y que fuera menos arriesgado

\footnotetext{
7 CERVANTES, 1998, II, cap. LI: 1049.

8 ECHARRI, I: 90-92.

9 CAMPOMANES, 1978.
} 
arreglarlas (...) Puede haber ciertamente en esta diversión, como en todas, algunos excesos y peligros, pero ninguno inaccesible al desvelo de una prudente policía ${ }^{10}$.

Aunque en esta Memoria la propuesta de Jovellanos apunta a una tolerancia renegociable, Pedro Fraile ha recordado que el político asturiano examinaba la realidad con el fin de exigir una mayor perfección en su funcionamiento, para hacer compatibles omnipresencia e invisibilidad, ubicuidad y discreción ${ }^{11}$. De ser así, al tratar sobre los espectáculos y diversiones, y sobre cómo tolerar las transgresiones, Jovellanos estaba ya en la antesala de la transformación de los sistema legales y penitenciarios que se pondrán en práctica en toda Europa y América durante el siglo XIX. Los reformistas ilustrados mezclaban propuestas sobre la observancia religiosa, las buenas costumbres con otras que incidían en la necesidad de actitudes disciplinadas para el funcionamiento de la sociedad. Coincidían con la corriente que se abría paso en buena parte de Europa a fines del XVIII, la llamada ciencia de la policía. Esta política estatal la había resumido el francés Delamare en once campos: religión, moralidad, salud, abastecimientos, carreteras, canales, puertos y edificios públicos, seguridad pública, artes liberales, comercio, fábricas, servidumbre y labradores y pobres ${ }^{12}$. Donde se desarrollaron «estos elementos constitutivos de la vida de los individuos», como dijo Foucault, se reforzó también «la potencia del Estado» ${ }^{13}$.

Sin embargo, esta cesura no fue tan clara en la España borbónica. Es cierto que el rey y sus ministros se obsesionaron con la vigilancia del orden público, mientras que las autoridades episcopales, cercanas al jansenismo pero aún más con una aversión instintiva hacia lo popular, intentaron desterrar las supersticiones y la inmoralidad de los actos religiosos populares ${ }^{14}$. Como demostró María José del Río, los bandos en el Madrid de fines del XVIII «expresan menos preocupación por la presencia de elementos profanos en las ceremonias religiosas que por el ‘desorden’ y la ‘confusión’ que podía producirse en ellas» ${ }^{15}$.

Para los gobiernos borbónicos pesó mucho, y de qué manera, el miedo a la multitud. Es conocido, por ejemplo, como tras el motín de Esquilache se recontextualizó el carnaval en el espacio teatral, convertido ahora en espectáculo. Más allá de las represiones y las constantes transgresiones ${ }^{16}$, Alberto Me-

10 JOVELLANOS, 1982: 127-128.

11 FRAILE, 1997,120.

12 CALVO, 2011: 25-26.

13 FOUCAULT, 1990: 132.

14 DOMÍNGUEZ ORTIZ, 1981: 378; LÓPEZ MUÑOZ, 21 (Granada, 1993-1994): 277; MORGADO, 28 (Alicante, 2010): 186.

15 RÍO BARREDO, 1988: 307.

16 RÍO BARREDO, III (Madrid, 2002): 111-129. 
dina considera que la nueva lógica simbólica y política — de un pueblo sometido al guión del Estado a través del espectáculo de sí mismo- adquirió a lo largo de la segunda mitad del siglo dimensiones más amplias y complejas. Desde este enfoque en el juego de máscaras, convertido en una dinámica de seducción de clases, «la transgresión será permisible y de hecho incentivada en forma de 'pose' para, precisamente, exorcizar indeseados roces sociales y políticos. Se trata de 'representar' una concordia y proximidad entre clases para alejar posibles cuestionamientos de la estructura 'real' de esa misma sociedad ${ }^{17}$. Ante el peligro que suponía la multitud para el poder se impone una renovada tutela que, para Medina, podía ser ignorada a conveniencia. De ahí que «la tolerancia del proyecto moderno no es tanto producto del ideal filosófico ilustrado, como del miedo que no le es posible exorcizar» ${ }^{18}$.

Estamos en el siglo XVIII y todavía, parafraseando a Sahlins, la realidad social/cotidiana no tenía ninguna obligación de corresponder a las categorías con las que había sido pensada o, mejor dicho, representada ${ }^{19}$. Dicho de otro modo, si bien, la religión era un elemento estructurador de la sociedad, presente en todos los niveles, en los espacios urbanos y rurales se desplegaban una tipología amplia de prácticas, si se prefiere un conjunto polimórfico de lógicas de coexistencia cotidianas, que oscilaban entre la norma y la transgresión. Prácticas que en el mundo rural eran moralmente muy escandalosas en el ámbito urbano podían parecer más homologadas por el contexto en que se desarrollaban, véanse determinados juegos o comportamientos nocturnos. Del mismo modo, aspectos cotidianos de cierta tolerancia entre grupos populares o subalternos podían ser vistos como muy transgresores en el seno de la clase dirigente de cada lugar, llámense bebidas o bailes, por ejemplo. Así, la línea roja la marcaba el escándalo, la violencia o el hambre. Como constató Caro Baroja, la Iglesia pudo controlar las herejías, pero le costó Dios y ayuda dominar los usos y costumbres más populares, que en muchas ocasiones contaban con la permisividad de los poderes locales ${ }^{20}$. En su viaje por España a fines del siglo XVIII, el barón de Bourboing reconocía en que se había hecho un esfuerzo reformista por reprimir comportamientos, por «revolucionar las costumbres»: "podemos aducir en prueba del cambio operado en las costumbres españolas la casi absoluta desaparición de los duelos». Sin embargo, admitía que no todo había sido abolido, y ponía dos ejemplos: las rondallas y las pedreas: «Tales costumbres acusan tanto a los que las conservan como al Gobierno que las tolera» ${ }^{21}$.

\footnotetext{
17 MEDINA, 2009: 186.

18 MEDINA, 2009: 222.

19 SAHLINS, 1982.

20 CARO BAROJA, 1984: 261.

21 GARCÍA MERCADAL, 1999: 495.
} 


\section{DESMANES FESTIVOS}

Desde mediados del siglo XV, en Europa occidental las fiestas constituyeron un aspecto más del discurrir cotidiano. Tan sólo las fiestas religiosas, incluidos los domingos, superaban el centenar. Ante la imparable decadencia española, los arbitristas y los moralistas propusieron diversas medidas encaminadas a su control y reducción. Pedro Fernández de Navarrete en su Conservación de monarquías (1626) relacionaba «la holgazanería con la muchedumbre de fiestas de guardar que se ha introducido; siendo cierto que en muchos obispados pasan de la tercera parte del año, sin los días de toros y otros regocijos públicos, y si se repara en ello, se hallará que el mes de agosto, que es el mes más ocupado de todo el año con la cosecha de los labradores, tiene tantas fiestas como días feriados». A la cantidad de fiestas se sumaba que con motivo de ellas «se gastan y consumen las haciendas en juegos, glotonerías y vicios»²2.

Las desviaciones y excesos de las prácticas festivas estaban a la orden del día. En las fiestas religiosas abundaban los comportamientos de muchos eclesiásticos que no se diferenciaban mucho de los de sus fieles, adoptando una actitud comprensiva y tolerante con prácticas poco ortodoxas. La preocupación de la Iglesia por eliminar todo tipo de prácticas profanas en los templos es constante desde los sínodos de fines del XV y comienzos del XVI. Por ejemplo, en el de Jaén de 1492 ya se hacía referencia a no permitir «hacer juegos ni representaciones deshonestas, ni comer ni beber en ellas, ni ejercer otras mercaderías ni negociaciones mundanas». Y una y otra vez similares situaciones, u otras diversas, pero con semejante frecuencia se prohíben por entorpecer el culto en los sínodos de Guadix (1554), Granada (1565,1572), Toledo (1582), Almería (1607), Sevilla (1512, 1604), Málaga (1671), etc.

En ese sínodo malagueño insistieron nuevamente en la imperiosa necesidad de dignificar la liturgia en el interior del templo o en la calle, como sucedía durante las cruces de mayo. Era habitual que los vecinos se reuniesen alrededor de «algunos altares con pretexto de devoción, y a ellos acuden mucha gente de día y de noche a hacer bailes y decir cantares profanos, cometiéndose muchas indecencias y ofensas de Dios en los concursos de hombres y mujeres, que no por devoción, sino por gozar de aquellas fiestas nada loables». Los controles que debían ser aplicados en la Semana Santa iban más allá del tiempo y del espacio de la procesión. En las dichas sinodales del obispado de Málaga se ordenó que habiendo vuelto a la iglesia de donde salieron «todos los penitentes vayan a desnudarse a sus casas, sin andar vagando por las calles con pretexto de visitar las iglesias sin otro fin piadoso». El intento no era que otro que evitar actos casi carnavalescos: «Después andan por las calles

22 FERNÁNDEZ NAVARRETE, 1626: discurso XIII. Sobre la críticas a los excesos en las fiestas madrileñas de la segunda mitad del XVII véase también RÍO BARREDO, 2008. 
haciendo insultos y deshonestidades con el disfraz de las túnicas de que hacen máscaras, para más libre y licenciosamente, no siendo conocidos, hacer ofensas a Dios» ${ }^{23}$. Un siglo más tarde, y a juzgar por la prohibición hecha en Almagro en 1793, era costumbre todavía en algunos pueblos — pese al decreto de 1777- predicar en la noche de Jueves Santo y hacer la procesión de Soledad el viernes, al ponerse el sol, y después la fiesta continuaba: «pues lejos de concurrir a los templos se ejercitan en otros hechos más opuestos y contrarios a tan santo tiempo, en términos que muchas veces más parecen Carnestolendas que Semana Santa» ${ }^{24}$.

Los desórdenes eran aún más escandalosos si se producían por la noche. El visitador eclesiástico del Campo de Calatrava en 1754 denunció los abusos que se cometían en los alrededores de las ermitas en Villarrobledo, en las que los jóvenes usaban velas nocturnas a pesar de estar prohibidas por las sinodales para iluminar sus fiestas. El visitador pedía el cierre de la ermita de Santa María de la Sierra con el fin de «quitar los bailes impúdicos entre ambos sexos, con las muchas palabras lascivas y acciones deshonestas, como también el que entren muchas uvas y melones para comer, tirándose unos a otros los escobajos de uvas y cortezas de melón, con palabras de mozuelos y mozuelas, y todo esto delante de Nuestra Señora dentro de la misma iglesia, como si fuera zahúrda» ${ }^{25}$. En ocasiones, estos comportamientos ponían al descubierto las tensiones entre las autoridades civiles y eclesiásticos de la misma localidad. El obispo de Orihuela excomulgó en 1753 al Ayuntamiento de Alicante porque no aceptó cambiar de la tarde a la mañana la procesión del Corpus. El clero más rigorista se quejaba de que las autoridades civiles no eran más duras con las transgresiones nocturnas. Así lo hicieron los obispos de Cádiz, de Salamanca, de Barcelona, de Teruel o de Orihuela a través de pastorales y sermones. En 1752 el obispo de Solsona lo explicó al rey: «en algunas festividades de la inmaculada Virgen María, y santos, con unos festines nocturnos de comedias y bailes, que puedo asegurar a Vuestra Majestad que a más de innumerables culpas y caídas interiores que ocasiona la desordenada confusión de ambos sexos, apenas hay mudanza sin injuria del pudor» ${ }^{26}$.

Será a raíz del Expediente General de Cofradías, encargado por Carlos III en 1767, cuando el Gobierno conozca en detalle muchas de las transgresiones que se hacían del tiempo y del espacio sagrado en las romerías y demás fiestas religiosas. En 1769 el arzobispo de Tarragona se quejaba de los excesivos gastos de las cofradías en «cera y música y lo que derraman profusamente en

23 PÉREZ DE COLOSÍA, 1989: 1002-1005.

24 DÍAZ-PINTADO, 1987: 220.

25 MARTÍNEZ GIL y RODRÍGUEZ GONZÁLEZ, 2004: 310.

26 MARTÍNEZ GOMIS, 2002: 158. Sobre las actuaciones rigoristas del obispo Pérez de Prado en Teruel véase LATORRE, 2005; 355-358. 
refrescos, comilonas, huéspedes, máquinas de pólvora, bailes, danzas y juegos y otras funciones profanas y muy ajenas del verdadero espíritu de devoción y culto de los santos». Pero su crítica más dura será la que escriba sobre la Semana Santa, una denuncia que acercaban más las fiestas nocturnas de esos días al carnaval que a la pasión de Cristo:

\footnotetext{
Vuelven a sus casas entre las dos y tres horas de la noche a pelotones y con algazara, cantando, saltando y escandalizando por los caminos, sin más temor ni respeto que si fueran noches del carnaval y, como el príncipe de las tinieblas ejerce su especial dominio entre las sombras de la noche, se aprovecha con astucia de tiempo tan concurrido y oportuno para que ni se tribute al templo el respeto que se le debe, ni se veneren con religiosa devoción los misteriosos pasos de dichas procesiones, antes bien se ve y observa que los concurrentes no se detienen en hablar confusamente, reír en demasía, tirar dulces...».
}

En ese mismo año, el arzobispo de Burgos comentaba también el indebido el uso que se hacían de los reiteradamente prohibidos fuegos artificiales durante las procesiones: «Al pueblo ocioso, que llaman con árboles y cohetes, y ya se saben las malas consecuencias que tienen por la noche las mezclas distintas». ${ }^{27}$ Aunque las procesiones nocturnas habían sido prohibidas en 1777, tres años más tarde el obispo de Canarias fray Joaquín de Herrera tuvo que prohibir las funciones nocturnas en las iglesias de su diócesis: «se ve una licencia desenfrenada, una disipación escandalosa en los más moderados, y lo que lleva al último punto la iniquidad es que con la oscuridad de la noche en lo exterior como en el interior de la iglesia se comenten obscenidades y la lascivia ha inventado modos con que saciar los apetitos en los lugares más sagrados». Las protestas fueron inmediatas y la oposición a ese cierre la encabezó el cabildo tinerfeño quien directamente acusó a los eclesiásticos y a los jueces de haber llegado a esta situación por su tolerancia y disimulo ante la impiedad, «puesto que no velan sobre la descarriada conducta de sus ovejas y de sus súbditos, ni les firman causas, no los castigan por los delitos más atroces y sacrílegos» ${ }^{28}$. La fiesta como derroche, desenfreno y nocturnidad dividía y enfrentaba no sólo a los grupos populares con las autoridades civiles y eclesiásticas, sino a las autoridades entre ellas mismas. A fines del XVIII la noche seguía siendo un problema para los grupos dirigentes. Entre 1788 y los comienzos del siglo XIX se probaron numerosas y distintas medidas, como la creación del Cuerpo de Serenos, para reducir cualquier manifestación multitudinaria - ya fuese en noches tan señaladas como San Juan,

27 AHN, Consejos, legs. 7090-91 (ARIAS DE SAAVEDRA y LÓPEZ GUADALUPE, 2002: 314 y ss.)

${ }^{28}$ HERNÁNDEZ, 2000: 150. 
Navidad, Carnaval,...-, para prohibir bailes y músicas nocturnas o para limitar los horarios de las tabernas ${ }^{29}$.

Durante la noche el tiempo y los gestos transgresores eran más difíciles de controlar $^{30}$. Ya lo había comentado en 1604 Francisco de Sales. Su crítica a los bailes nocturnos se basaba en que "por medio de las tinieblas y oscuridades, es muy acomodado a deslizar en muchos accidentes tenebrosos y viciosos, en materia que de suyo es tan susceptible del mal». Le obsesionaba el peligro de la noche. En sus discursos se representaba este tiempo como arriesgado y rechazable:

Y en una palabra digo, que es locura siempre trocar el día con la noche, la luz con las tinieblas, las buenas obras con las lascivas. Llevan todos a los bailes vanidad a porfía; y la vanidad es tan grande disposición a los malos afectos, y a los amores peligrosos y detestables, que con facilidad se engendra en las danzas todo esto ${ }^{31}$.

Era habitual que las danzas y los bailes se practicasen en distintos espacios sacralizados $^{32}$. En las constituciones de Jaén de 1492 prohibieron que en las ermitas se hiciesen «danzas y bailes y otras deshonestidades». Pero su persistencia llevó al obispo Baltasar Moscoso en el Sínodo de 1624 a restringir y limitar diversas celebraciones - fueran concejos, mercados, autos, comedias,...- en las iglesias y ermitas ${ }^{33}$. Los bailes eran unas de las diversiones más recurrentes entre los jóvenes. Según el jesuita Pedro de León, en las aldeas de Aracena hacia 1614 había «una muy mala costumbre: que los días de fiesta se salían a la plaza los mozos y mozas doncellas de los lugares y todos bailaban juntos mozos con mozas; y aunque toda es gente sana, no deja de haber un sentimiento o algún coco o gusano que hacía pudrir la fruta; y con resolución se los afeamos muchos en todas las aldeas» ${ }^{34}$. Aunque los clérigos se opusieron de una manera más rigurosa a los bailes, las autoridades eclesiásticas fueron más permisivas siempre y cuando no se realizaran en recintos religiosos. Las constantes prohibiciones - como la famosa del arzobispo Palafox en el Corpus sevillano de fines del XVII ${ }^{35}$ - confluyeron en el decreto de Carlos III de 1777 que prohibía el baile en los templos, sus atrios y cementerios en toda España, aunque es sabido que continuaron después de la prohibición según el vicario general de Barcelona ${ }^{36}$. Con Carlos IV se reiteraron

29 MARTÍNEZ RUIZ, 1988.

30 PEÑA, 2013: 302-305.

31 SALES, 1789: 312-313.

32 GÓMEZ VOZMEDIANO, 2012, 152.

33 LÁZARO, 1989: 292-294.

34 LEÓN, 1981: 158.

35 DOMÍNGUEZ ORTIZ, 1987: 211-212.

36 KAMEN, 1998: 179. Sobre la alegación de Campomanes y el discurso del obispo de 
las prohibiciones en Madrid de los bailes nocturnos en el paseo del Prado y en las eras del campo (1789), se impuso también la separación de sexos en las escuelas de baile (1790), e incluso se prohibieron las danzas de los asturianos que vivían en la Corte (1803) ${ }^{37}$.

\section{LAS ROMERÍAS}

De manera colectiva y cotidiana, la pérdida de la rutina tomó en las romerías formas y comportamientos que sobrepasaron, como en ninguna otra fiesta, la capacidad de control de las élites eclesiásticas y políticas. Ya a fines del siglo XVI, Castillo de Bobadilla aconsejaba cómo debía actuar el corregidor ante las romerías y sus escándalos:

Y harto más decente sería que los Corregidores y Ayuntamiento acompañasen las tales procesiones de letanías, e hiciesen que el Ordinario mandase ir a ellas los eclesiásticos, según lo dispone el Concilio Tridentino, que no consentir las dichas comidas y bebidas: si ya no fuesen muy moderadas, y por legítima costumbre introducidas ${ }^{38}$.

El exceso en los comportamientos de los romeros también se había censurado en las constituciones sinodales de Jaén (1492, 1624), Granada (1572), Córdoba (1662), Toledo (1566), etc. A pesar de la pena de excomunión que estos sínodos establecían para los transgresores, las prácticas habían continuado en todas las romerías de las que tenemos referencias, sin duda, toleradas por la costumbre. Así sucedió en una de las más antigua y celebrada romería andaluza, la que se celebraba en honor a la Virgen de la Cabeza en Andújar (Jaén), según relataban los jesuitas en los siglos XVII y XVIII:

Particularmente era caso escandalosísimo el abuso que en esta ciudad había los días inmediato a la ida de Nuestra Señora de la Cabeza, en los cuales innumerable gente de hombres y mujeres salían al campo y a los caminos por donde los que iban y venían a esta fiesta de Andújar, ciudad, aquí vecina, era fuerza que pasasen y allí era la desenvoltura tanta en los hombres y mujeres, que no solo perdían el temor a Dios, sino aún la honestidad natural, y a voces y con gritos decían mil palabras deshonestas y daban matracas y cordelejos, ocasión de muchas pendencias, alborotos, riñas, heridas y muertes ${ }^{39}$.

Palencia que consideraron el baile delante de las imágenes devotas como una profanación de lo sagrado, por acto indecente y supersticioso véase RÍO BARREDO, 1988: 304.

37 RÍO BARREDO, 1988: 301.

38 CASTILLO DE BOBADILLA, 1704, 578.

39 AHDJ, mss. Historia de la entrada y misión de la Compañía de Jesús en Jaén (1617, 1763). Una transcripción de dicho manuscrito en LÓPEZ ARANDIA, 2005: 340. 
Desde mediados del siglo XVI se intentaba regular estos comportamientos. En 1569 un sacerdote creó una capilla de música compuesta por niños para cantar letanías y coplas de la Concepción de Nuestra Señora, «llevando en unas andas el Buen Pastor, con que estorben piadosamente aquella vocería, y les hacen cesar». No lo consiguión ${ }^{40}$. Ni tampoco las autoridades eclesiásticas tuvieron éxito en intentos posteriores. El 2 de junio de 1769 el arzobispo de Granada se quejaba que en esta romería se juntaban «muchos vecinos de los lugares y emprenden el viaje, haciendo a porfía grandes prevenciones de comida y bebida, con que se disponen a cometer en el camino los excesos más escandalosos de la rustiquez y la vanidad, (...) sin que hayan bastado para corrección y enmienda las moniciones y providencias del prelado de la diócesis de Jaén» ${ }^{41}$.

Los intentos de domesticar esta romería se dirigirán también desde el cabildo municipal. En sus actas capitulares son frecuentes las referencias a cómo actuar y cómo estar representado en la romería ${ }^{42}$. Había conflictos permanentes derivados de la resistencia de los romeros a que la fiesta se regulase según las normas de las autoridades. En 1733, ya que no bastaban las admoniciones del obispo de Jaén, se consultó al Consejo de Castilla sobre los «excesos, desvergüenzas, escándalos y pecados» que se cometían en la fiesta. Se pedía que se le diese poder al corregidor y a los diputados y otras "personas de categoría que le acompañan» para imponer penas de azotes, entre otras, a los transgresores, sin necesidad de que tuviesen que consultar con la Real Chancillería de Granada ni otros estamentos oficiales. En 1769, se dio a conocer una Real Provisión en la que se ordenaba no permitir la menor estafa ni incidencia a los marchantes y vendedores que asistían con sus tiendas y puestos a la fiesta en el Santuario. Hubo que repetirla en 1772.

La situación en el Cerro nunca llegó a estar controlada, y durante algunos años la asistencia de las autoridades fue escasa con la excusa de ahorrar dinero. Sin embargo, cuando el desenfreno superaba los límites de la costumbre hubo de asistir de nuevo. Así sucedió en 1778 cuando el cabildo acordó acudir a la fiesta del Santuario de Sierra Morena. En esta ocasión fueron el corregidor, dos regidores y un jurado. Se adujo como razón de ello la gran asistencia de fieles y las muchas pendencias y disputas que estaban produciéndose y que los capitulares asistidos de los guardas tenían que evitar.

Pero no todos los conflictos eran consecuencia de comportamientos que transgredían las leyes. En otras ocasiones las tensiones procedían de otras causas. En 1722, se nombraron los regidores comisarios para la fiesta del Cerro según costumbre de todos los años. Sin embargo, ninguno de los asisten-

40 FRÍAS, 1994: 229.

41 AHN, Consejos, leg. 7090.

42 TORRES, 1981. 
tes aceptó el nombramiento, por el «notorio encono, gran enemiga y mala voluntad que tienen los de Arjona en contra de la cofradía de Andújar». El año anterior se habían producido graves incidentes, por lo que los de Andújar pensaban no ir a la fiesta, si iban los de Arjona. El corregidor propuso ir a Baeza acompañado de los regidores para visitar al obispo de Jaén y prevenirle de lo que estaba sucediendo, al tiempo que le iba a solicitar «graves censuras eclesiásticas» que impidiese que los arjoneros asistiesen a la fiesta, o en su defecto a los de Andújar, hasta que legalmente se resolviese esta situación de primacía entre unos y otros. Por como transcurrió la romería en los años sucesivos debieron ser los iliturgitanos los que vencieron a los arjoneros.

En otros lugares sucedieron episodios similares. En la romería que cada segundo domingo de mayo se celebraba en honor de la Nuestra Señora de la Herrera, que según el cura de Navalucillos (Toledo) se había convertido en un lugar propicio para «libertinaje, palabras obscenas e impuras, embriagueces y desórdenes, blasfemias, juramentos, dichos escandalosos y otros excesos», un desorden moral de hombres y mujeres que dormían juntos, en «que no hay reparo en abrazarse y darse ósculos las personas de uno y otro sexo». En su celebración coincidían vecinos de tres pueblos toledanos, y como eran abundantes las noticias sobre conflictos entre ellos, desde 1671 se ordenó que nadie fuese armado durante los tres días que duraba la romería. Al fin, el cura de Navalucillos consiguió acabar con esta romería en 1773 trayendo la imagen de la ermita a su parroquia, con la excusa de una rogativa para pedir agua. El episodio derivó en un enfrentamiento entre los vecinos de los pueblos que, en la práctica, era también una resistencia a la agresión eclesiástica de domesticar la romería que, en este caso, se volvió a celebrar unos años más tarde aunque sólo en Navalucillos ${ }^{43}$.

En la mayoría de las romerías las decisiones restrictivas eran potestad de los visitadores pastorales, pero como las medidas que estos adoptaban se incumplían de manera reiterada, a veces eran las mismas hermandades o cofradías las que intentaban regularlas. Así sucedió en 1723 con la romería de Nuestra Señora de los Milagros de Palos (Huelva), donde se obligó a sus miembros «a celar que no se toquen instrumento en los ranchos, ni se cante ni se baile ni se den carga, porque esto de ha de ser una feria espiritual y no pasatiempo» ${ }^{44}$. En las peregrinaciones y romerías catalanas se repetían situaciones similares, con prohibiciones constantes y transgresiones permanentes. Kamen pone como ejemplo el comentario casi resignado que se incluyó en el sínodo de 1683 de Barcelona: «en la presente diócesis hay abuso que en muchos lugares hacen procesiones anuales extra propriam parrochiam, y cuando llegan a la capilla o santuario destinado se trata más de mercar y vender, co-

43 MARTÍNEZ GIL y RODRÍGUEZ GONZÁLEZ, 2004: 309 y 315.

44 LARA RÓDENAS, 2000:150. 
mer y beber, que del culto divino» ${ }^{45}$. A mediados del siglo XVIII la teología pastoral del obispo Climent fue más incisiva con la intención de separar lo folklórico y popular de lo religioso, prohibiendo romerías y los tradicionales «aplecs» a ermitas, santuarios o parroquias vecinas. El argumento era el mismo, los desórdenes

que amb capa de devoció ha introduit i fomentat lo maligne esperit en notori dany espiritual i corporal dels concorrents..., per això no podent tolerar semblant abominació i excés... Per lo que toca fora de la església, requerim i estretament encarregam al Batlle i demés ministres de justicia que en descàrrec de sa obligació celen amb la major vigilància i cuidado castigant, en quan es menester sia, severíssimament als transgressors ${ }^{46}$.

Era necesaria e imprescindible que en cada lugar, en cada diócesis colaborase en la represión la autoridad civil, que conocía también que ese espacio y ese tiempo de las romerías se escapaban al control de las normas y leyes vigentes. En los informes que elaboraron los intendentes a fines de 1769, a instancias del Consejo de Castilla, para conocer el estado de las cofradías abundan también referencias a comportamientos en fiestas romeras que «perturban la paz y quietud de los pueblos». El comentario del intendente de Ávila sobre lo que acaecía en los alrededores de las ermitas expresa cual era la principal preocupación de los grupos dominantes con sus autoridades al frente:

Tampoco faltan aquellos sujetos, libertinos, díscolos y malcriados, los cuales se hallan dispuestos y preparados para levantar motines y abrazar toda maldad, y se les quieren contener se burlan o mueven quimeras o alborotos, especialmente si la función es en algún santuario que no está en población, y de éstas es rara en donde no haya desazones de no buenas resultas ${ }^{47}$.

A fines del siglo XVIII el reformismo festivo en consonancia con el rigorismo moral de la élite eclesiástica había fracasado. Son numerosas las referencias a continuos altercados y desórdenes en el discurrir de las romerías. En la de la Cinta en Huelva tuvo que intervenir el corregidor en varias ocasiones para intentar reprimir dichos comportamientos, o al menos para dejar claro donde residía la autoridad en un tiempo y en un espacio donde no era reconocida, o más bien olvidada temporalmente. En 1770 se prohibió «que ninguna persona diga ni oiga cantares torpes ni deshonestos, ni eche equívocos provocativos ni digan chanzoletas ni sátiras a las mujeres ni las acompañen en romería». En 1792 se intentó limitar el horario —la medianoche- de estancia

45 KAMEN, 1998: 183-184.

46 TORT, 1978:285.

47 ARIAS DE SAAVEDRA y LÓPEZ-GUADALUPE, 2002: 314 y ss. 
en la ermita y de venta de bebidas y comestibles. Y de nuevo en 1793 el corregidor tuvo que recordar todas las prohibiciones, y de manera más detallada la referida al consumo de licores y reduciendo el límite horario a las once de la noche. De poco sirvió, porque en 1837 se tenía que seguir convocando la policía para que «conserven el orden y la tranquilidad pública» en la velada de la Cinta ${ }^{48}$.

Recuerda también Tomás Mantecón que las constituciones sinodales del arzobispado de Brugos de 1575 estuvieron vigentes en el obispado de Santander — creado en 1754 — hasta 1884. En ellas como es sabido se condenaban y prohibían las conductas escandalosas que suponían «graves ofensas a Dios» en "cantares deshonestos», danzas «y otras cosas indecentes donde se siguen muchos escándalos e inconvenientes y pecados». Pero no sería hasta mediados del Setecientos cuando muchas de estas prácticas fueran especialmente censuradas en visitas pastorales. Sin embargo, como refiere Mantecón, a fines del siglo XVIII tales transgresiones persistían. Con tal insistencia lo hacían, que un ilustrado cántabro, José Manso, comentaba en 1798 que «en ningún día hay mayor desorden que en los de fiesta, la embriaguez, la lujuria, la gula, en una palabra, todas las pasiones predominantes parece que están reservadas para el día festivo, en que se presentan al público quitada la máscara del rubor» ${ }^{49}$.

Las romerías estuvieron durante siglos fuera de control, y en el XVIII se convirtieron en un campo de tensiones y fuerzas entre la cultura popular y las agresiones ilustradas. Feijoo lo había dejado bien claro en 1730: «Sólo quien no haya asistido alguna vez a aquellos concursos, dejará de ser testigo de las innumerables relajaciones que se cometen en ellos. Ya no se disfraza allí el vicio con capa de piedad: en su propio traje triunfa la disolución. Coloquios desenvueltos de uno a otro sexo, rencillas, y borracheras son el principio, medio, y fin de las romerías. Eso se hace, porque a eso se va». Apariencias, escasa religiosidad, y fiesta, pura fiesta, sexo y alcohol:

Todo es fiesta en la fiesta. Todo es jovialidad en la Romería. En las conversaciones, pretextando el regocijo, se pasa la raya de la decencia. Habla la lengua más de lo que dicta la razón, y los ojos hablan algo más que la lengua. Hácese generoso el más mezquino: promete con largueza el que no tiene que dar aún con escasez. Todo se cree, porque el distraimiento del espíritu estorba toda cuerda reflexión. A la sombra del bullicio crece en un sexo el atrevimiento, y en otro la confianza.

Para Feijoo los remedios era una combinación de represión y tolerancia ante el temor a conflictos y sobre todo ante el fracaso por resistencias popula-

48 DÍAZ HIERRO, 1967: 262-264.

49 Estado de las Fábricas, la Agricultura, la Industria y el Comercio en las Montañas de Santander, 1789 (MANTECÓN, 1990: 198). 
res: «¿Que se quiten enteramente? No me atrevo a proponerlo; porque las reformas extremas, que por precaver los abusos quieren no sólo cortar las ramas viciosas mas también arrancar las raíces, suelen tener gravísimos inconvenientes. ¿Que se permita a la frecuencia del concurso no más que la mitad del día, hasta concluir la Misa solemne? Creo que será muchas veces impracticable» ${ }^{50}$.

No se debe trasladar el éxito relativo en la represión de las cofradías a partir de $1769^{51}$ a un supuesto sometimiento y reconducción de las romerías, que aunque se intentó no pudo superar las «inconvenientes» populares, que tanto temía Feijoo. Suprimir las fiestas transgresoras sin ofrecer alternativas de expresión era fomentar la contestación. Para Jesús Pereira, la política de desmantelamiento de cultura popular fracasó por la resistencia de las clases populares, y porque el proyecto ilustrado no ofrecía nada a cambio. La religiosidad popular estaba fuera de control, a pesar del disciplinamiento tridentindo del tiempo y del espacio, de las formas y de las devociones ${ }^{52}$.

Un caso singular que ilustra muy bien los límites del poder de las autoridades civiles se denunció el 30 de diciembre de 1795 en el lugar del Almendro, jurisdicción del condado de Niebla en el reino de Sevilla. Las autoridades se dirigieron al Rey informando de «los desórdenes que se cometen el segundo día de Pascua de Resurrección en la fiesta y procesión del Santuario de la Virgen de Piedras Albas». Para ello presentaron un memorial sobre cuales eran las causas y consecuencias de dichos desórdenes. La primera causa tenía que ver, según ellos, con «la relajación de los tiempos» de cuarenta años a esta parte. Antes aseguraban «no se vendía en el recinto de aquel santuario vino, aguardiente, ni otro licor alguno espirituoso, ni se veía disolución alguna, ni cosa que oliese a función profana». Dicha relajación tenía que ver —en primer lugar y siempre según las autoridades - con el comensalismo promovido y costeado por los mayordomos. Estos convites atraían — como en tantas romerías - a muchos lugareños que se exhibían «con el adorno y compostura que sus facultades les permiten, y aún a este fin se procuran ajenas galas o se compran para lucir, empeñándose». Aunque la confusión de las apariencias había sido una crítica recurrente desde siglos atrás, el gran problema se derivaba del alcohol, cuyo abuso era una consecuencia directa tanto de los referidos convites como de la fácil disponibilidad ante los numerosos puestos de

50 FEIJOO, 1775: 98-108.

51 Aunque en general el control de las cofradías no pasó de ser testimonial, sus efectos a medio y largo plazo resultaron decisivos (ARIAS DE SAAVEDRA y LÓPEZ-GUADALUPE, 2002: 147). Sobre la ofensiva reformista de las elites eclesiásticas desde 1750, en alianza con el Estado, para controlar prácticas religiosas que consideraban extravagantes y supersticiosas véase también CALLAHAN, 1989: 72-76.

52 PEREIRA, 1988: 254. 
venta ubicados alrededor del Santuario. El verdadero espectáculo del que se quejaban las autoridades se iniciaba con el regreso a casa de los romeros, propiciado por los que iban a caballo, tanto en el camino como por las calles del Almendro:

El camino que hay desde la ermita al pueblo, que es de sierra, es pedregoso, cerrado y estrecho, y como transitan muchas gentes en aquella ocasión por él, muchas personas, que de intento llevan buenas caballerías para correr en el tránsito, ya amostazados, y después de haber bebido con demasía, atropelladamente dan riendas a los caballos y mulas, y con el mayor desorden los traen corriendo en tropas, a toda carrera, atropellando hombres, mujeres y niños y bestias, hiriendo y maltratando a muchos, y en varias ocasiones los mismos corredores se precipitan cayéndose, atropellándose, hiriéndose, reventándose y matándose, de que hay no sólo un ejemplo, como de sus resultas haber algunas personas.

El problema surgía cuando las autoridades locales querían «contener semejantes desórdenes, pues, al intentarlo, los atropellan dichos corredores, que ya no están en estado de saber obedecer, antes bien, por el contrario, con entusiasmo hacen sus desórdenes, caso de religión y obsequio de la Virgen, y tienen por indevotos a los que representan, porque se oponen a sus excesos». Ahí radicaba el conflicto, las carreras con los caballos formaban parte de los comportamientos devotos, la embriaguez de los caballistas era un agravante, pero tan sólo eso. La transgresión era la norma esos días de romería: «Los que representan no pueden contenerlos sin exponerse a un ultraje público, y tal vez a alguna conmoción popular, pues el vulgo es mucho, y no distinguen lo que es culto regulado, devoción verdadera o falsa». Las autoridades, desprovistos esos días de poder efectivo, solicitaban que el Rey prohibiese que los mayordomos diesen convites multitudinarios, que se vendiese alcohol en aquel sitio y que se corriese a caballo o con mulas o mulos. El Consejo de Castilla remitió el asunto al Regente de la Audiencia de Sevilla para que actuase en consecuencia ${ }^{53}$. Nada cambió hasta fines del siglo XX y comienzos del XXI, cuando el espacio sagrado se convirtió en un paisaje brutalmente urbanizado.

Estas resistencias interesan al historiador como reivindicaciones prácticas y puntuales de arraigadas formas de tolerancias o coexistencias dentro de la comunidad, y no necesariamente como prácticas rupturistas del orden social dominante. En las romerías las armas ordinarias de los grupos sin poder se desplegaban con más facilidad y aceptación ${ }^{54}$. Bajo la aparente aceptación del

53 AHN, Consejos, leg. 1674, 39.

54 Sobre las posibilidades teóricas y metodológicas que ofrecen los términos «armas del débil» y «formas cotidianas de resistencia campesina» véanse los distintos trabajos en el dosier «James C. Scott y los dominados», Historia Social, 77 (Valencia, 2013), y como síntesis de su pensamiento y de sus trabajos anteriores SCOTT, 2013. 
status quo y las muestras de sumisión y de aceptación del discurso público se escondían corrientes de resistencia y un cuestionamiento generalizado de las normas que beneficiaban a las elites civiles y eclesiásticas. En las romerías observamos como los dominados podían asumir aparentemente y en determinadas prácticas el pensamiento hegemónico de los grupos dominantes, pero no por ello eran incapaces de desarrollar una alternativa al discurso oficial sobre la fiesta religiosa y su devoción. Que no hubiese oposición directa no suponía que existiese un amplio consenso social.

Pero ni siquiera el discurso oficial era único. Como reconoce Emilio La Parra, las disputas religiosas habidas durante el reinado de Carlos IV fueron más enfrentamientos entre minorías dirigentes, entre los partidarios y los contrarios a las Luces, que intentos claros y contundentes de transformar la religiosidad de la sociedad española ${ }^{55}$. Es comprensible que el contexto constitucional gaditano, los diputados liberales desconfiasen de la Curia para reformar la Iglesia en España. Bajo la influencia galicano-febroniana y dentro de la religiosidad jansenista, los diputados plantearon en 1811 una reforma profunda en la «Memoria de algunos puntos de disciplina externa que las Cortes Generales y Extraordinarias de España presentan al examen del Concilio Nacional», insistiendo en la necesidad de reconducir estas fiestas religiosas más populares:

Atendida la irreverencia con que suelen hacerse ciertas procesiones o visitas públicas del clero y del pueblo a algunos santuarios distantes, y el riesgo, de que en estas prácticas piadosas se mezclen comilonas, embriagueces, riñas y otros males acreditados por una triste experiencia: si convendría suprimir estas procesiones... conmutándolas en otras más cortas por el recinto del pueblo o en otros actos de piedad que fomenten el espíritu de verdadera devoción ${ }^{56}$.

\section{LAS FERIAS}

Durante el siglo XVIII, las ferias parecen superponerse a las romerías como otras formas nuevas o renovadas de sociabilidad. Ambas se escapaban, en algunos aspectos festivos, al control de la Iglesia y de las autoridades civiles, y en ambas se entrecruzaban en distintas secuencias las normas y las transgresiones, las imposiciones y las resistencias, y las negociaciones.

Las ferias se habían convertido, según el corregidor de Orense, en 1790, en «el objeto de más atención de sus naturales, que con una sola vaca o una caballería corren cuantas hay, que son infinitas, vendiendo y cambiando aunque

55 LA PARRA, 1985: 18.

56 LA PARRA, 1985: 284. 
de ello no les resulte más ganancia que la necesaria para comer pan de brona y tomar vino». Como ha recordado Pegerto Saavedra, el desorden mayor derivado del excesivo número de ferias afectaba a la administración de las rentas provinciales. Uno de lo administradores afincado en Galicia señalaba como causa principal de tantísimas ferias «la tolerancia de los arrendadores» de rentas provinciales respecto al fraude ${ }^{57}$.

Las ferias que se extendían por toda la Península se celebraban con periodicidad fija y permanecían bajo la especial protección tanto de las autoridades centrales como de las municipales. En el siglo XVIII no se llegó a recuperar el dinamismo de las ferias castellanas del XVI, ante el resurgir de la periferia marítima y la progresiva constitución de una tupida red de tiendas, filiales en muchos casos de las botigas catalanas. Sin embargo, en la segunda mitad del Setecientos y hasta bien entrado el siglo XIX aumentó el número de ferias y mercados. Un incremento que, según Alberto Marcos, se explicaría por el proceso de ruralización que venia experimentando la economía castellana desde fines del siglo XVI. Así la mayoría de estas ferias o mercados habían quedado reducida al intercambio rural de productos agropecuarios, principalmente ganado ${ }^{58}$. Estas ferias eran tiempos y espacios donde desembocaba la vida cotidiana con la máxima expectación ${ }^{59}$. La impresión que le causó a Francisco Pérez Bayer llegar a Fernán Núñez, la noche del 17 de julio de 1782, y encontrarse a este pueblo cordobés en plena feria, es un excelente ejemplo de la intensidad de las vivencias festivas en las que se entrelazaban la actividad económica y las diversiones públicas:

Estaba este pueblo cuando llegué a él (que serían las diez de la noche) ardiendo en bailes y lleno de gente con motivo de la feria. No vi en aquella hora sino barracuelas o cabañas donde se vendían buñuelos, aguardiente y vino, y estaban bien frecuentadas de tropas de hombres y mujeres, y me figuré que así estaría Roma en los días de Bacanales. Sic magnus componere parva solebam.

Tomé por cena una jícara de chocolate y me acosté, pero es indecible el ruido, las coplas y cánticos y la bulla que anduvo aquella noche por el pueblo y las tropas y cuadrillas de gentes que discurrían por él. Una copla que decía «Turin por la mañana compone al hombre, y Peneque por la tarde lo descompone» quise saber la erudición que contenía, y me dijeron que «Turin» era el aguardiente o chapurrado y «Peneque» el vino. Así se pasó la noche hasta la madrugada ${ }^{60}$.

Todo podía bordear la norma e incluso transgredirla si era de noche y había alcohol por medio, pero siempre que el poder y la imagen de las autoridades

57 SAAVEDRA, 1994: 287-289.

58 MARCOS, 1999: 118-122.

59 Sobre la expectación en la vida cotidiana véase PEÑA, 2012.

60 PÉREZ BAYER, 1998: 336. 
locales no se pusieran en entredicho por su debilidad o tolerancia a la hora de reprimir los excesos. Así sucedió en Córdoba a fines del XVIII, con una secuencia de norma, transgresión, prohibición, resistencia y negociación. En 1789 el Cabildo municipal recibió una carta ordinaria del Consejo de Castilla pidiendo ciertos informes sobre las ferias que se celebraban en esta ciudad y extramuros. El 28 de junio respondió el alcalde mayor José Cebrián con un detallado memorial. En él concretaba que las ferias se celebraban en los días de Pascua de Espíritu Santo, 24 de junio, 25 de julio, 28 de agosto y 8 de septiembre. Además de compraventa de ganado, se concentraban unas cuatrocientas tiendas en las que se vendían todo tipo de manufacturas, comestibles, y entre las que se encontraban un «crecido número de puestos con licores». En primer lugar, el alcalde realizaba una precisa descripción del espacio de las ferias y como este lugar propiciaba los desórdenes:

Como aquellas se celebran en las estaciones más rigurosas del año, resulta una concurrencia numerosa, por la noche en aquel paraje en las gentes de ambos sexos esparcidas por el dilatado campo, y sus inmediaciones que se hallan situadas en un terreno alto, montuoso y con huertas inmediatas, cuya espesura presta fomento para todo género de excesos imponderables.

En segundo término, el alcalde consideraba que al entorno impropio se añadía el tiempo que favorecía la transgresión, la noche: «la citada concurrencia tiene su mayor fuerza en la venta de comestibles, bebidas heladas y licores y desde poco antes de oscurecer hasta las dos o tres de la mañana». En tercer lugar, exponía detenidamente como la participación de muchos vecinos daba lugar a una verdadera explosión de desórdenes que aprovechaban algunos delincuentes para cometer delitos. El miedo a la multitud:

Como la citada ciudad es una población cuantiosa y la mayor parte de menestrales y artesanos, propensos naturalmente a diversiones bulliciosas, y la errada inteligencia de ellos, persuadidos con libertad para estas concurrencias a deshora de la noche, se evidencia con este motivo una multitud de alborotos, ruidos y quimeras. Y a los sujetos que tal vez ha faltado ocasión para lograr sus fines siniestros, se les proporciona con el tropel y confusión.

El paternalismo del alcalde ponía en evidencia como los tiempos y espacios de la juventud se escapaban al control de las autoridades, «y lo que es de mayor consideración que algunas hijas e hijos de familia y sirvientas, sin noticia de sus respectivos superiores, con notable riesgo de su integridad, salen de sus casas acompañadas de los jóvenes con quien comunican, porque entienden bajo el errado concepto que en semejantes noches todo es disimulable». La situación se convertía en explosiva al participar, como era habitual, lo más bajo 
de la sociedad cordobesa del momento junto a los soldados destinados a los cuarteles de la ciudad: «que ni estos ni aquellos viven bajo las reglas de recogimiento a determinada hora, como lo practican en sus respectivos cuerpos. Concurren también con el mayor escándalo, ocultándose con las mujeres prostitutas en los citados sitios para cometer sus carnales excesos». En su memorial el alcalde realizaba un pormenorizado análisis sociológico de la ciudad, de sus relaciones sociales y de los conflictos. Así, para completar el paisaje humano no podían faltar los trabajadores del campo y el recurso al alcohol:

Las precitadas ferias son asignadas en los días más solemnes, que son cuando los jornaleros y restantes operarios del campo, desde los cortijos, se presentan en el pueblo a recoger los salarios devengados en los anteriores días. Y como encuentran pábulo, cebándose en los licores, expenden todo lo ganado en perjuicio de sus hijos y familia, sin arbitrio después para el ordinario sustento de ellos, de lo que resultan algunas fatales consecuencias.

Reconocía que la vigilancia con las patrullas de ronda era insuficiente, «porque como la extensión del paraje se dilata a bastante terreno aparente para todo crimen, cuando se presentan cortando unos, dan principio los otros». Para el alcalde, el escándalo mayor se daba en la combinación alcohol y sexo: «y propiamente es una confusión y abandono, llegando a tanto que se valen del medio inicuo de embriagar algunas incautas mujeres para lograr allí mismo sus depravados intentos, cuyo desorden ha tocado personalmente el referido Alcalde Mayor; y en el año pasado de 88 se encontraron sujetos de diversos sexo, públicamente en las posturas más indecentes y lascivas». El alcalde terminaba dando dos razones definitivas para que se prohibiesen. Primero, consideraba que la ciudad no tenía ningún privilegio de la Corona para celebrar dichas ferias. Y por último, y porque al parecer le había afectado personalmente, advertía que estos desórdenes perjudicaban «la fama y opinión de las familias honradas, expuestas a los graves sentimientos que pueden acarrearles sus hijos con estas nocturnas juntas» ${ }^{61}$.

La repuesta fue rápida, el 1 de agosto de 1789 el Consejo de Castilla ordenó la suspensión de las ferias por los referidos desórdenes, «hasta que se tome providencia para evitarlos y se averigüen las cédulas o privilegios que tiene esa Ciudad para celebrar estas ferias». Las protestas debieron ser numerosas e insistentes, e incluso podemos intuir que la resistencia de los cordobeses se manifestase con organizar al margen del Ayuntamiento algunas de estas ferias en 1790. El cabildo municipal tuvo que rectificar, y solicitó el 16 de abril de ese mismo año que continuasen las ferias con el argumento de ser muy necesarias para ganaderos y agricultores. Por si no fuera suficiente, tuvieron que contrade-

61 AMCO, C-198, doc. 6. 
cir al alcalde mayor demostrando que sí tenían privilegio — el ya conocido de Sancho IV de 1322—, eso sí admitieron reducir el número de ferias:

que de tiempo inmemorial celebra dos ferias anuales: la una en la Pascua del Espíritu Santo y la otra el día ocho de septiembre en virtud del antiguo privilegio que tiene para ello en donde sus labradores y los de las villas y lugares comarcanos venden y compran sus ganados y demás producciones del país para cumplir sus contratas.

La urgencia era tal que se comprometían a organizarla «por la premura del tiempo, pues solo restan ocho días para la Pascua, y para evitar semejantes quebrantos: Suplico a Vuestra Alteza se sirva mandar que sin perjuicio de la providencia que venga a bien tomar el Consejo en dicho expediente se celebre la feria por ahora». Fue tal la celeridad que recibieron un decreto con fecha de 18 de mayo que les permitía de manera provisional celebrar la feria de ese mismo mes, pero cuidando que no se cometiesen excesos ni abusos. El 30 de agosto hubieron de recurrir de nuevo a la urgencia de pedir que concedieran otro decreto para la feria del 8 de septiembre. Y así sucedió, el día 4 el Consejo daba otro permiso provisional. Y por fin el 20 de septiembre recibieron una Real Provisión de Carlos IV, en el que se permitía las dos ferias, aunque que se limitaba el horario hasta las diez de la noche y «que se observe y de que se eviten cualesquiera excesos y desórdenes, que se adviertan no permitiendo mujeres en los puestos de licores» ${ }^{62}$.

De esta secuencia de norma, transgresión, prohibición, resistencia y negociación surgieron nuevas normas, y no sólo respecto al tiempo también en relación al espacio. Y quizás ese fuese el éxito más importante de las autoridades. En 1792 se desplazó el lugar de celebración de la feria. Se abandonó el terreno más montuoso y más difícil de controlar por una cercana explanada más adecuada para la exposición de ganado, según comunicó el corregidor Pascual Ruiz:

que habiendo de celebrar una feria pública en virtud del Real privilegio en la próxima Pascua de Pentecostés o venida del Espíritu Santo, en el sitio y paraje del Campo de la Victoria, por ser el más acomodado y ancho para los muchos ganados de todas especies, que concurren a ella, y colocación de tiendas y comestibles, como igualmente para el desahogo y extensión de las muchas gentes que acuden.

Nuevas normas se imponían. El corregidor ordenó que el alguacil mayor fuese el encargado de ordenar y colocar las tiendas, previa petición de una licencia por escrito. Las tiendas no podían permanecer abiertas después de la diez de la noche, y para que todos se diesen por enterados se tocaría por tres

62 AMCO, C-198, doc. 7. 
veces un tambor. Además se advertía que en ninguna tienda podía haber «mujeres mozas vendiendo». Y si en la feria hallaban algún delincuente, le exigía al alguacil mayor y los justicias «procuren su aprehensión y captura con sutileza y precaución, para evitar en lo posible alboroto, que conmueva la gente, o pueda seguirse algún escándalo o desgracia funesta»63.

Y comenzaba de nuevo una secuencia de transgresión, prohibición, resistencia y negociación. Así en 1800, el corregidor Gregorio Guazo tuvo que recordar las medidas que no se cumplían, aunque aceptaba ampliar el horario de cierre de tiendas:

que todos los concurrentes, así de día como de noche, guarden y cumplan los autos de buen gobierno, evitando disgusto y pendencias, y cuantos motivos sean o puedan ser causa de ellas, ya con las embriagueces, ya con las mofas, gritos o burlas de unos con otros. Que los vendedores de licores no permitan se introduzcan en sus tiendas mujeres notadas de mala conducta o no conocidas, ni tampoco que haya mujeres algunas, aunque sean propias, vendiendo en dichas tiendas.

El auto era extenso y preciso sobre la circulación del ganado, sobre los corredores, sobre la presencia de gitanos y sobre el tránsito de persona y coches. Y para que las diversiones no se desbordasen por la vía del incumplimiento concedió «que todos los tenderos, aguardenteros, buñoleros y turroneros y demás vendedores en dicha feria irremisiblemente a las once de cada noche, $\mathrm{y}$ al toque del tambor hayan de echar los toldos». Además advertía que las autoridades conocían la existencia de distintos espacios en las tiendas de licores, uno público y otro tapado por cortinas. Si descubrían estos escondrijos los tenderos eran condenados a la pena de tres días de cárcel y dos ducados. Todo continuó más o menos igual hasta bien entrado el siglo XIX. En 1851 todavía estaban intentando modelar la feria de mayo y se preguntaban, entre otras cuestiones, si «¿fuera prudente anteponer o posponer a los días principales de la venta las diversiones públicas?». En 1853 se propusieron regular por fin el número de tiendas para «que además de ofrecer cómoda estancia a toda clase de vendedores pondrá en armonía la decencia uniforme de los puestos con la importancia de un mercado a que concurre una parte numerosa de la provincia y aún de las limítrofes» ${ }^{64}$.

63 AMCO, C-200.

${ }_{64}$ AMCO, C-200. Una excelente aproximación a la historia de la feria de Córdoba en VERDÚ, 2007. 


\section{CONCLUSIÓN}

Se ha escrito y repetido con mucha frecuencia que no fue hasta el siglo XVIII cuando las autoridades civiles y eclesiásticas alcanzaron éxitos notorios en el disciplinamiento de las fiestas: la prohibición o la metamorfosis del carnaval es un ejemplo entre tantos. Pero ni las reformas ni las represiones tuvieron el alcance deseado. La actitud de la Iglesia fue prudente, limitándose a reafirmar la imagen de su autoridad y a erradicar lo que consideraba que profanaba notoriamente y en exceso. Esta actitud reformista fue similar a la del Gobierno, si la represión podía provocar tensiones y sonoras protestas era mejor seguir tolerando la costumbre. Los cambios introducidos «a la fuerza no siempre pudieron resistir a largo plazo la lenta presión de la costumbre, o a corto plazo, la fuerza del entusiasmo» 65 .

En las fiestas barrocas se conjugaban valores de contenido dispar, sacros y profanos, populares y cultos,... El poliédrico y formal ritual barroco se consolidó con tal fuerza y aceptación que apenas cambió hasta principios del XIX, la fiesta del Setecientos estuvo arraigada en modelos anteriores. Quizás el mayor cambio fueron las alarmas ante tanto desenfreno y los intentos de reformarlas ${ }^{66}$. Los desmanes festivos no se reducían al desorden y al abuso del alcohol, sino a la exposición de prácticas rabelesianas y de rituales de bromas, risas e inversión social que variaba en su forma entre una comunidad y otra, o un contexto u otro. Así podían ser vistas como una amenaza para la estructura dominante o como rituales alternativos en una etapa de la vida del ser humano pero no transformadores del conjunto ${ }^{67}$.

Represión y resistencia se exponían en los espacios y en los tiempos de lo cotidiano. Pero, como hemos visto, para poder apreciar los márgenes de tolerancia es necesario incidir no sólo en los esquemas de relaciones establecidos socialmente y dominantes en lo simbólico, sino también en las prácticas que se insertaron en las estructuras según relaciones contingentes ${ }^{68}$. La tolerancia fue una forma cotidiana persistente y mucho más pública que clandestina. Estamos ante prácticas, comportamientos, establecidos por la costumbre en un sentido invertido al protagonismo social que apunta la 'economía moral de la multitud' de Thompson. Son actitudes que se desarrollan dentro de unos límites tolerados, soportables, que pueden ser considerados intolerables, inaceptables, por las autoridades según la situación social específica y determinada.

65 CHRISTIAN, 1991: 12.

66 BARROSO, 1995.

67 Se interprete según la propuesta de Max Gluckman o la de Víctor Turner (KAMEN, 1998: 163).

68 REGUILLO, 2000. 
Entendido de este modo, la vida cotidiana y sus manifestaciones no representaron una sumisión a la estructura, sino más bien una readaptación continua a las categorías dominantes en cada momento, fuesen eclesiásticas o civiles, fueran jurídicas o consuetudinarias. Como ha demostrado Tomás Mantecón, disciplina y represión no enunciaban una misma realidad, las comunidades podían ampararse en costumbre y defender el orden que ésta definía, pasando a ser las intrusiones prácticas ilícitas ${ }^{69}$. ¿Dónde estaba la frontera de la tolerancia hacia esas costumbres? Para las autoridades locales las concurrencias en las romerías o en las ferias no eran únicamente un problema moral, donde únicamente ponían la condena los predicadores, moralistas y autoridades eclesiásticas. Cuando los riesgos de desórdenes que desembocasen en altercados eran muy altos, las autoridades retomaban las prohibiciones ya decretadas por el rey. Mientras las tensiones no desbordasen los márgenes de tolerancia, las condenas de los sínodos no tenían ninguna trascendencia, más allá de la reiteración en la forma más adecuada.

En esos espacios y tiempos cotidianos rayanos a la transgresión se formulaban prácticas racionales, coherentes en sí mismas con experiencias inmediatas y futuras ${ }^{70}$. Cuando se vulneraban pactos amparados por la costumbre se manifestaban formas cotidianas de resistencia que obligaban a negociaciones, fuesen sobre espacios o tiempos o sobre los límites de las mismas prácticas. Durante las fiestas los individuos no solamente replicaban comportamientos aprendidos, sino que eran agentes activos construyendo su propia realidad sin sentirse obligados a compartir la totalidad de significados, sino que participaban según su experiencia social ${ }^{71}$. Es comprensible, por ejemplo, que la fiesta religiosa no se pudiese reducir a su dimensión procesional, se organizaba - en palabras de Alain Cabantous- alrededor de otros gestos que tenían también funciones ambivalentes, fuese en las comidas o en los bailes ${ }^{72}$. Las iglesias eran, desde esa vivencia, espacios de confusión, y los alrededores de las ermitas eran a un tiempo espacios naturales y paisajes sagrados. Las tentaciones profanadoras eran aún mayores cuando las acciones represivas o pedagógicas de la Iglesia o del Estado eran conocidas, pero sus ejecutores estaban ausentes, o incluso estaban presentes como en determinados momentos de las romerías cuando la fuerza de la costumbre de un pueblo hacía suyo el recinto, los actos y el culto a realizar.

Lejos de una realidad inmóvil, en las calles, en los paseos, en las alamedas o en las plazas, las sociabilidades festivas oscilaron entre el respeto al orden social y la indisciplina crónica. Los hechos festivos en lugares públicos se

69 MANTECÓN, 1997.

70 Sobre la economía de las prácticas sigo a BOURDIEU, 1991.

71 Tomo la idea de BUXÓ, 1989: 8.

72 CABANTOUS, 2002: 44. 
erigieron en disputados espacios de dominación en los que se exhibían la ostentación y el prestigio, y donde el culto a las apariencias fue el consenso ante posibles conflictos. Mientras, las fiestas continuaron, aunque fueran menos. En definitiva, la mercantilización y el crecimiento económico del siglo XIX, con la ampliación del tiempo laboral en detrimento de los días feriados, fueron más efectivos que el disciplinamiento tridentino y el reformismo social borbónico.

\section{BiBLIOGRAFÍA}

Arias de Saavedra, Inmaculada y López-Guadalupe, Miguel Luis, La represión de la religiosidad popular. Crítica y acción contra las cofradías en la España del siglo XVIII, Granada, Universidad, 2002.

Barroso, $\mathrm{M}^{\mathrm{a}}$ Dolores, «Fiestas religiosas en la Ilustración gaditana. La pervivencia del ritual barroco y sus imbricaciones profanas», en Alberto Romero (coord.), IV Encuentro de la Ilustración al Romanticismo. Juego, Fiesta y Transgresión 17501850, Cádiz, Universidad, 1995; 189-196.

Benigno, Francesco, Las palabras del tiempo. Un ideario para pensar históricamente, Madrid, Cátedra, 2013.

Bourdieu, Pierre, El sentido práctico, Madrid, Taurus, 1991.

Buxó, M Mesús, «Introducción», en Carlos Álvarez Santaló, Mª Jesús Buxó Rey y Salvador Rodríguez Becerra (coords.), La religiosidad popular. II: Vida y muerte: la imaginación religiosa, Barcelona, Antrophos, 1989; 7-13.

Cabantous, Alain, Entre fêtes et clochers. Profane et sacré dans l'Europe moderne, XVIIe-XVIIIe siècle, París, Fayard, 2002.

Callahan, William J., Iglesia, poder y sociedad en España, 1750-1874, Madrid, Nerea, 1989.

Calvo Maturana, Antonio J., «Aquel que manda las conciencias...». Iglesia y adoctrinamiento político en la Monarquía Hispánica preconstitucional (1780-1808), Cádiz, Ayuntamiento, 2011.

Campomanes, Pedro Rodríguez de, Discurso sobre la educación popular, ed. de F. Aguilar Piñal, Madrid, Editora Nacional, 1978.

Caro Baroja, Julio, El estío festivo, Madrid, Taurus, 1984.

Castillo de Bobadilla, Jerónimo , Política para Corregidores (1597), Amberes, Juan Bautista Verdusse, 1704.

Cervantes, Miguel de, Don Quijote de la Mancha, ed. de F. Rico, Barcelona, Instituto Cervantes - Crítica, 1998.

Christian, William, Religiosidad local en la España de Felipe II, Madrid, Nerea, 1991.

Díaz Hierro, Diego, Historia de la devoción y culto a Nuestra Señora de la Cinta, patrona de Huelva, Huelva, Tipografía Girón, 1967. 
Díaz-Pintado, Juan, Conflicto social, marginación y mentalidades en La Mancha (siglo XVIII), Ciudad Real, Diputación, 1987.

Dodds, Jerrilynn D. y Glick, Thomas F. (eds.), Convivencia: Jews, Muslims and Christians in Medieval Spain, Nueva York, George Braziller \& The Jewish Museum, 1992.

Domínguez Ortiz, Antonio, Sociedad y Estado en el siglo XVIII español, Barcelona, Ariel, 1981.

Domínguez Ortiz, Antonio, La Sevilla del siglo XVII, Sevilla, Universidad, 1987.

Echarri, Francisco de, Directorio moral, Madrid, Imprenta Real de la Gazeta, 1779.

Egido, Teófanes, «La religiosidad de los ilustrados», en Ramón Menéndez Pidal (dir.) Historia de España, Madrid, Espasa-Calpe, 1987, vol XXXI; 396-437.

Feijoo, Benito Jerónimo, Teatro crítico universal (1726-1740), tomo cuarto (1730). Madrid, Real Compañía de Impresores y Libreros 1775.

Fernández Navarrete, Pedro, Conservación de monarquías y discursos políticos, Madrid, Imprenta R., 1626.

Foucault, Michel, Tecnologías del yo y otros textos afines, Barcelona, Paidós, 1990.

Fraile, Pedro, La otra ciudad del rey. Ciencia de policía y organización urbana en España, Madrid, Celeste Ediciones, 1997.

Frías, Rafael, «Las cofradías de la Virgen de la Cabeza en el Reino de Jaén durante los siglos XVI y XVII», en Juan Aranda (coord.), Congreso de Religiosidad Popular en Andalucía, Córdoba, Ayuntamiento de Cabra - CajaSur, 1994; 221-230

García Mercadal, José, Viajes de extranjeros por España y Portugal, Valladolid, Junta de Castilla y León, 1999, t. V.

Gómez Vozmediano, Miguel F., «Fiesta, religión y trasgresión en la Castilla barroca», Dimensión Antropológica, 55 (mayo/agosto 2012); 151-180.

Hernández González, Manuel, «Fiesta y sociedad en Canarias durante el siglo XVIII», en Margarita Torrione (ed.), España festejante. El siglo XVIII, Málaga, Diputación, 2000; 145-154.

Jovellanos, Gaspar Melchor de, Espectáculos y diversiones públicas. Informe sobre la Ley Agraria, ed. de J. Lage, Madrid, Cátedra, 1982.

Kamen, Henry, Cambio cultural en la sociedad del Siglo de Oro. Cataluña y CastiIla, siglos XVI-XVII, Madrid, Siglo XXI, 1998.

La Parra, Emilio, El primer liberalismo y la Iglesia. Las Cortes de Cádiz, Alicante, Instituto Gil-Albert, 1985.

Lara Ródenas, Manuel José de, «Los mundos devotos en la Hueva del Antiguo Régimen: perfiles y contextos», en David González (ed.), Religiosidad y costumbres populares en Iberoamérica, Huelva, Universidad, 2000; 127-152.

Latorre, José Manuel, «Rigorismo moral y defensa de la jurisdicción eclesiástica por Francisco Pérez de Prado, obispo e Inquisidor General», en Antonio Luis Cortés, José Luis Betrán y Eliseo Serrano (eds.), Religión y poder en la Edad Moderna, Granada, Universidad de Granada, 2005; 353- 380. 
Lázaro Damas, María Soledad, «Ermitas y santuarios de la ciudad de Jaén en el siglo XVI», en Carlos Álvarez Santaló, Ma Jesús Buxó Rey y Salvador Rodríguez Becerra (coords.), La religiosidad popular. III Hermandades, romerías y santuarios, Barcelona, Antrophos, 1989; 282-301.

León, Pedro de, Grandeza y miseria de Andalucía, ed. de P. Herrera, Granada, Facultad de Teología, 1981.

López Arandia, Ma Amparo, La Compañía de Jesús en la ciudad de Jaén: El colegio de San Eufrasio (1611-1767), Jaén, Ayuntamiento, 2005.

López Muñoz, Miguel Luis, «La fiesta religiosa en la diócesis de Granada (17501825). Opinión, control y represión», Chronica Nova, 21 (Granada, 19931994);239-278.

Mantecón, Tomás A., Contrarreforma y religiosidad popular en Cantabria. Las cofradías religiosas, Santander, Universidad de Cantabria, 1990.

Mantecón, Tomás A., Conflictividad y disciplinamiento social en la Cantabria rural del Antiguo Régimen, Santander, Universidad de Cantabria, 1997.

Marcos Martín, Alberto, España en los siglos XVI, XVII y XVIII. Economía y sociedad, Barcelona, Crítica, 1999.

Mariana, Juan de, Tratado contra los juegos públicos, Obras, II, BAE, XXXI, Madrid, Atlas, 1950; 460-475.

Martí, Marc, Ciudad y campo en la España de la Ilustración, Lleida, Milenio, 2001.

Martínez Gil, Fernando y Rodríguez González, Alfredo, «La fiesta en el mundo rural (siglos XVII-XVIII)», en Palma Martínez-Burgos y Alfredo Rodríguez (coords.), La Fiesta en el Mundo Hispánico, Cuenca, UCLM, 2004; 281-319.

Martínez Gomis, Mario, «La noche y los noctámbulos en el siglo XVIII español», en Ángel Vaca (ed.), Fiesta, juego y ocio en la Historia, Salamanca, Universidad, 2002; 147-171.

Martínez Ruiz, Enrique, La seguridad pública en el Madrid de la Ilustración, Madrid, Ministerio del Interior, 1988.

Medina, Alberto, Espejo de sombras. Sujeto y multitud en la España del siglo XVIII, Madrid, Marcial Pons, 2009.

Mestre Sanchis, Antonio, «Religión y cultura en el siglo XVIII español» en Ricardo García-Villoslada (dir.), Historia de la Iglesia en España, Madrid, BAC, 1979, vol. IV; 583-743.

Moreno, Doris, «De la Reforma Católica a la Contrarreforma. Algunas reflexiones», en Alvaro Castro y otros (coords.), Franciscanos, místicos, herejes y alumbrados, Córdoba, Editorial Séneca - Universidad de Córdoba, 2010; 251-272.

Morgado, Arturo, «La reforma de la fiesta religiosa en el Cádiz de fines del siglo XVIII», Revista de Historia Moderna, 28 (Alicante, 2010): 185-199.

Olivari, Michele, «Consideraziones sulle premesse e prospective della storiografia italiana sulla controriforma e sul disciplinamento social», en Eliseo Serrano, An- 
tonio Luis Cortés y José Luis Betrán (coords.), Discurso religioso y Contrarreforma, Zaragoza, IFC, 2005; 101-140.

Peña, Manuel, «La vida cotidiana en la época moderna: Disciplinas y rechazos», Historia Social, 66 (Valencia, 2010); 41-56.

Peña, Manuel, «Conceptos y relecturas de lo cotidiano en la época moderna», en M. Peña (ed.), La vida cotidiana en el mundo hispánico, siglos XVI-XVIII, Madrid, Abada, 2012; 5-18.

Peña, Manuel, «Los tiempos en la vida cotidiana (siglos XVI-XVII», en Máximo García Fernández (ed.), Cultura material y vida cotidiana moderna: escenarios, Madrid, Sílex, 2013; 279-306.

Pereira, Jesús, «La religiosidad y la sociabilidad popular como aspectos del conflicto social en el Madrid de la segunda mitad del siglo XVIII», en Equipo Madrid, Carlos III, Madrid y la Ilustración, Madrid, Siglo XXI, 1988; 223- 254.

Perez, Joseph, «La tolerancia. Evolución de un concepto», en Rica Amran (coord.), Violence et identité religieuse dans l'Espgane du XVe au XVIIe siècles, París, Indigo, 2011; 41-49.

Pérez Bayer, Francisco, Viajes literarios, ed. A. Mestre, P. Pérez y J. A. Catalá, Valencia, Ed. Alfons el Magnànim, 1998.

Pérez de Colosía, $M^{a}$ Isabel, «Rigorismo y manifestaciones populares: el sínodo de 1671», en Francisco J. Campos (coord.), Religiosidad popular en España, Madrid, 1997, pp. 991-1006.

Reguillo, Rossana, «La clandestina centralidad de la vida cotidiana», en Alicia Lindón (coord..), La vida cotidiana y su espacio-temporalidad, Barcelona, Antrophos - El Colegio de México, 2000; 77-94.

Río Barredo, María José del, «Represión y control de fiestas y diversiones en el Madrid de Carlos III», en Equipo Madrid, Carlos III, Madrid y la Ilustración, Madrid, Siglo XXI, 1988; 299-329.

Río Barredo, María José del, «Burlas y violencia en el Carnaval madrileño de los siglos XVII y XVIII», Revista de Filología Románica, extra III (Madrid, 2002); 111-129.

Río Barredo, María José del, «Francisco de Santos y su mundo: fiesta popular y política en el Madrid barroco", en Tomás A. Mantecón (ed.), Bajtin y la historia de la cultura popular, Santander, Universidad de Cantabria, 2008; 175-207.

Saavedra Fajardo, Diego de, Empresas políticas, ed. de Francisco J. Díez de Revenga, Barcelona, Planeta, 1988; 147-148.

Saavedra, Pegerto «La consolidación de las ferias como fiestas profanas en la Galicia de los siglo XVIII y XIX», en Manuel Núñez (ed.), El Rostro y el Discurso de la Fiesta, Santiago de Compostela, Universidad, 1994; 279-296.

Sahlins, Marshall D. ,«Individual Experience and Cultural Order», en William H. Kruskal (ed.), The Social Sciences: Their Nature and Uses, Chicago, University of Chicago Press, 1982; 35-48. 
Sales, Francisco de, Introducción a la vida devota (1604), Madrid, Plácido Barco, 1789.

Schwartz, Stuart B., Cada uno en su ley. Salvación y tolerancia en el Atlántico ibérico, Madrid, Akal, 2010.

Scott, James C., Elogio del anarquismo, Barcelona, Crítica, 2013.

Torres Laguna Carlos de, Andújar a través de sus actas capitulares (1600-1850), Jaén, Instituto de Estudios Giennenses, 1981.

Tort Mitjans, Francesc, El obispo de Barcelona Josep Climent i Avinent (1706-1781). Contribución a la historia de la teología pastoral tarraconense en el siglo XVIII, Barcelona, Balmes, 1978.

Verdú, Ana (dir), Tiempo de Feria: historia y carteles de las Feria de Córdoba, Córdoba, Diario Córdoba, 2007.

Recibido: 31/12/2013

Aceptado: 17/06/ 2014 